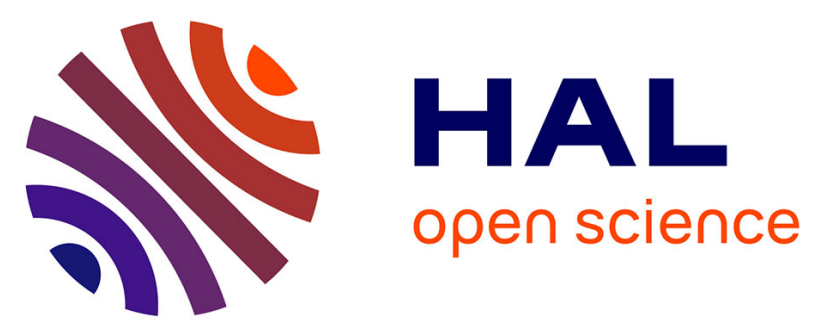

\title{
STRUCTURE OF CONCENTRATED SOLUTIONS OF LITHIUM SALTS IN AMMONIA. AN EXPERIMENTAL APPROACH OF THESE SYSTEMS
}

\author{
M. Herlem, B. Fahys
}

\section{- To cite this version:}

M. Herlem, B. Fahys. STRUCTURE OF CONCENTRATED SOLUTIONS OF LITHIUM SALTS IN AMMONIA. AN EXPERIMENTAL APPROACH OF THESE SYSTEMS. Journal de Physique IV Proceedings, 1991, 01 (C5), pp.C5-231-C5-236. 10.1051/jp4:1991527 • jpa-00250651

\section{HAL Id: jpa-00250651 https://hal.science/jpa-00250651}

Submitted on 1 Jan 1991

HAL is a multi-disciplinary open access archive for the deposit and dissemination of scientific research documents, whether they are published or not. The documents may come from teaching and research institutions in France or abroad, or from public or private research centers.
L'archive ouverte pluridisciplinaire HAL, est destinée au dépôt et à la diffusion de documents scientifiques de niveau recherche, publiés ou non, émanant des établissements d'enseignement et de recherche français ou étrangers, des laboratoires publics ou privés. 


\title{
STRUCTURE OF CONCENTRATED SOLUTIONS OF LITHIUM SALTS IN AMMONIA. AN EXPERIMEN- TAL APPROACH OF THESE SYSTEMS
}

\author{
M. HERLEM and B. FAHYS* \\ Laboratoire d'Electrochimie Interfaciale - CNRS, 1 place Aristide Briand, F-92195 Meudon cedex, \\ France \\ ${ }^{*}$ Laboratoire d'Electrochimie des Solides associé CNRS, U.F.R. des Sciences et Techniques, F25030 \\ Besançon cedex, France
}

\begin{abstract}
The electrical conductivities, viscosities and $\mathrm{NH}_{3}$ vapor pressure data for lithium salts ammoniates are reported. These measurements allow the apprehension of the nature of the solvation shell of ions by ammonia and the quantification of the $\mathrm{NH}_{3}-$ salt bonding energy which are essential for application of ammoniates as non aqueous electrolytes in lithium batteries.
\end{abstract}

\section{Introduction}

The research field on lithium batteries is now highly diversified and the choice of the electrolyte is of importance; it must satisfy a number of requirements including a good conductivity over a wide range of temperature, a liquid range from $-20^{\circ} \mathrm{C}$ to $+70^{\circ} \mathrm{C}$ and a thermal stability up to $70^{\circ} \mathrm{C}$. Liquid ammonia having medium dielectric constant $\left(16.9\right.$ at $\left.25^{\circ} \mathrm{C}\right)$ and low viscosity $(0.141 \mathrm{cp}$ at $20^{\circ} \mathrm{C}$ ) dissolves $\mathrm{Li}$ salts $\mathrm{LiX}$ giving concentrated solutions (salt concentration $>2 \mathrm{M}$ ) providing highly conductive solvates called "ammoniates" described by the general formula LiX.xNH3. A paradox is that lithium metal is thermodynamically unstable with respect to ammonia ; although it is very soluble in liquid ammonia according to :

$$
\mathrm{Li} \text { (solid) + ammonia } \Longrightarrow \mathrm{Li}^{+} \text {solvated }+\mathrm{e}^{-} \text {solvated. }
$$

we have found $/ 1 /, / 2 /$ that it is possible to shift the former equilibrium to the left by adding lithium ions and consequently lithium metal becomes insoluble in some lithium salt ammoniates which can be used as electrolytes for lithium batteries.

The optimization of performances of these solvates needs a good knowledge of their chemical, physical, electrical properties and of the lithium metal/electrolyte interface. From our following investigations, we have found that the nature of the Li salt plays a major rôle on these properties.

\section{Synthesis of the ammoniates and experimental techniques}

Most of the ammoniates were prepared by a stream of anhydrous ammonia onto the salt; Synthesis was carried out using carefully dried salts and anhydrous solvent as described previously $/ 1 /$. The composition is merely known by weighing and the water content in the ammoniates was determined to be less than $50 \mathrm{ppm}$ as determined by the Karl Fischer's technique. The ammoniates were stored and handled under an argon controlled atmosphere to avoid contamination.

\footnotetext{
* author to whom all correspondence should be addressed.
} 


\section{Results and discussion}

Dispersion effects of ammonia $\left(93 \mathrm{erg} \cdot \mathrm{cm}^{6}\right)$ are significantly more important than for water (47 erg.cm ${ }^{6}$ ) ; although dispersion forces generally can be neglected in ionic solvation, they become important for large ions which have relatively high polarizabilities. Thus from our study only nitrate, perchlorate, triflate salts are enough soluble in $\mathrm{NH}_{3}$ (salt concentration $>2 \mathrm{M}$ ) to give ammoniates wich are liquid at room temperature. The results presented in this section deal with these liquid ammoniates.

\subsection{Ionic species association}

Because of the medium dielectric constant of liquid $\mathrm{NH}_{3}$ even at low salt concentrations separated ion pairs predominate $/ 3 /$ except for $\mathrm{KNH}_{2}$ which gives contact ion pairs. In this work the ionic species association was studied using the temperature dependence of the specific conductivity $\chi$ of four typical systems $\mathrm{LiClO}_{4}-12 \mathrm{NH}_{3}, \mathrm{LiNO}_{3}-2.6 \mathrm{NH}_{3}, \mathrm{LiClO}_{4} 4 \mathrm{NH}_{3}$ and $\mathrm{LiSO}_{3} \mathrm{CF}_{3}-2.45 \mathrm{NH}_{3}$. Arrhenius plots $\log \chi=\mathrm{f}(1 / \mathrm{T})$ are shown Fig.1.

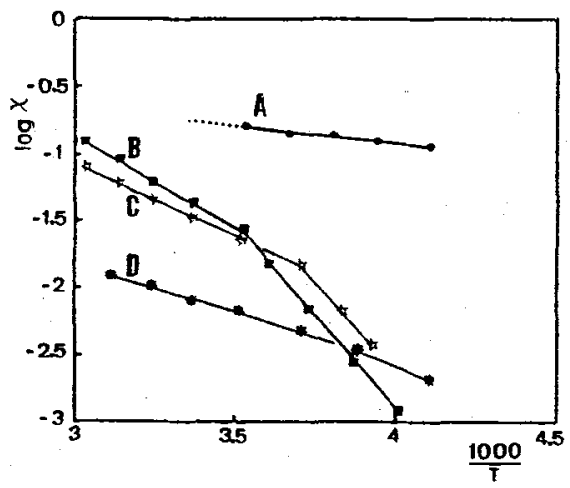

Fig 1 : conductivity vs $1 / \mathrm{T}$ for $\mathrm{LiClO}_{4}-12 \mathrm{NH}_{3}$ (A), $\mathrm{LiClO}_{4}-4 \mathrm{NH}_{3}$ (B), $\mathrm{LiNO}_{3}-2.6 \mathrm{NH}_{3}(\mathrm{C})$, $\mathrm{LiSO}_{3} \mathrm{CF}_{3}-2.45 \mathrm{NH}_{3}$ (D).

For $\mathrm{LiClO} 4$ and $\mathrm{LiNO} 3$ ammoniates (as well dilute as concentrated) the linear variations for every homogeneous phase can be described by an Arrhenius type relation

$$
\chi=A \exp \left(-E_{c} / R T\right)
$$

where $A=$ frequency factor and $E_{C}=$ activation energy for conduction.

For triflate ammoniate the three parameter Vogel Tamman Fulcher (VTF) equation /4/

$\operatorname{Ln} \chi=K_{\chi} / T-T_{0}+1 / 2 \operatorname{LnT}+\operatorname{LnA} \chi$ can be used to represent $\ln \chi$ vs $T,\left(K_{\chi}\right.$, To and $A_{\chi}$ are constants, with $K_{\chi} R=$ Arrhenius activation energy $\left(\mathrm{E}_{\mathrm{C}}\right)$ ).

The corresponding $\mathrm{E}_{\mathrm{C}}$ for ionic transport determined with these 4 typical electrolytes are reported Table I.

\begin{tabular}{|ll|c|}
\hline \multicolumn{2}{|c|}{ System } & $\mathrm{E}_{\mathrm{a}}$ in $\mathrm{eV}$ \\
\hline $\mathrm{LiClO}_{4}-12 \mathrm{NH}_{3}$ & Liquid T $>-30^{\circ} \mathrm{C}$ & 0.043 \\
\hline $\mathrm{LiClO}_{4}-4 \mathrm{NH}_{3}$ & $\left\{\right.$ Solid T $<9^{\circ} \mathrm{C}$ & 0.55 \\
& Liquid $\mathrm{T}>9^{\circ} \mathrm{C}$ & 0.26 \\
\hline $\mathrm{LiNO}_{3}-2.6 \mathrm{NH}_{3}$ & $\left\{\right.$ Liquid T $>-3^{\circ} \mathrm{C}$ & 0.26 \\
& $\left\{\right.$ Solid T $<-3^{\circ} \mathrm{C}$ & 0.55 \\
\hline $\mathrm{LiSO}_{3} \mathrm{CF}_{3}-2.45 \mathrm{NH}_{3}$ & $\left\{\right.$ Liquid T $>-10^{\circ} \mathrm{C}$ & 0.26 \\
& $\left\{\right.$ Solid T $<-10^{\circ} \mathrm{C}$ & -0.3 \\
\hline
\end{tabular}


Ionic conductivity and activation energy of the dilute solutions $\left(\mathrm{LiClO}_{4}-12 \mathrm{NH}_{3}\right.$ in our example) are comparable to that of aqueous electrolytes.

For concentrated solutions, large interactions between charged species are indicated by the lower values of $\chi$ as compared to those observed in concentrated solutions. The activation energy $E_{C}$ is equal to $0.26 \mathrm{eV}$. This $E_{C}$ 's value, below $0.3 \mathrm{eV}$, is of the order of magnitude to be expected in dilute electrolytes.

For perchlorate and nitrate ammoniates, below the freezing point the rapid decrease of conductivity and activation energy indicates the solvate crystallization, while for triflate ammoniate a glass forming point is reported as ionic conductivity can be described by a VTF equation without discontinuity in the curve shape.

The trend in ion-solvent associations is discussed in terms of specific interactions expressed by different functions describing the Hard and Soft Acids and Bases (HSAB) concept /5/ and donoracceptor interactions (6). The Electron Pair Donor $\mathrm{NH}_{3}\left(\mathrm{DN}=59.0 \mathrm{Kcal} \mathrm{mol}^{-1}\right)$ reacts on the one hand on the hard acid $\mathrm{Li}^{+}$to give complexes $\mathrm{Li}\left(\mathrm{NH}_{3}\right)_{x}+$ (with small values of $\mathrm{x}$ ) and on the other hand on the hard bases $\mathrm{SO}_{3} \mathrm{CF}_{3}{ }^{-}, \mathrm{ClO}_{4}^{-}$and $\mathrm{NO}_{3}^{-}$anions.

Typical structures are shown below
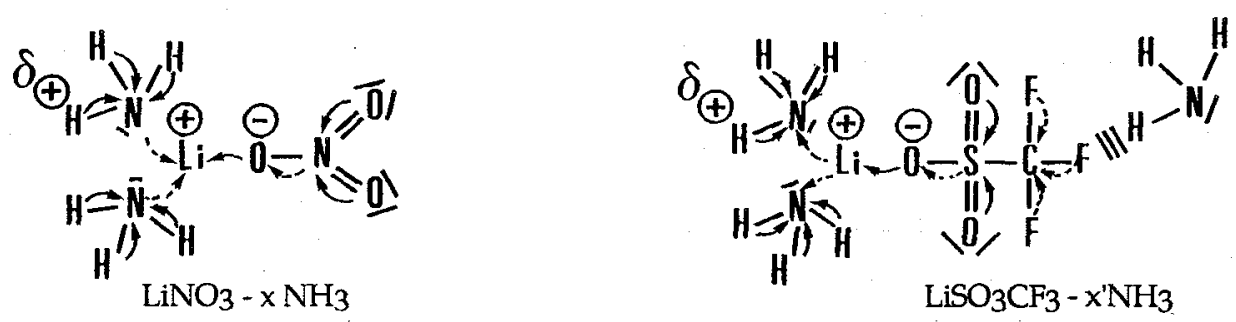

( $\simeq$ increase in bond distance ; $\because$ decrease in bond distance $; \equiv \mathrm{H}$. bond).

Thus for $\mathrm{LiNO}_{3}-\mathrm{x} \mathrm{NH}_{3}$ solvates, the structure is mainly due to ion-pair species without secondary bonds between the aggregates; the solvate gives rise to well ordered structure with a freezing point (crystalline solid) at high temperature; For $\mathrm{LiSO}_{3} \mathrm{CF}_{3}-\mathrm{x} \mathrm{NH}_{3}$ the possibility for building a network of secondary bonds (Hydrogen or Van der Waals bonds) gives a disordered structure with a quasi glassy solid at low temperature.

The experimental kinematic viscosities results for $\mathrm{LiClO}_{4}-3 \mathrm{NH}_{3}$ and $\mathrm{LiSO}_{3} \mathrm{CF}_{3}-2.9 \mathrm{NH}_{3}$ solvates, converted to absolute viscosities, are in agreement with the above interpretations. From controlled stress measurements the ammoniates (not thixotropic liquids) are not simple Newtonien fluids but incorporate a visco-elastic structure; therefore the flow curves were fitted to the Bingham equation :

$$
\tau=\tau_{\mathrm{o}}+\mathrm{K}_{\mathrm{b}} \gamma
$$

where $\tau_{0}=$ yield stress, $K_{b}=$ Bingham plastic viscosity, $\tau=$ shear stress, $\gamma=$ strain rate. Values generated for the constants in this equation are collected in table II.

\begin{tabular}{|c|c|c|c|c|}
\cline { 2 - 5 } \multicolumn{1}{c|}{} & \multicolumn{2}{c|}{$\mathrm{LiSO}_{3} \mathrm{CF}_{3}-2.9 \mathrm{NH}_{3}$} & \multicolumn{2}{c|}{$\mathrm{LiClO}_{4}-3 \mathrm{NH}_{3}$} \\
\hline $\mathrm{T}^{\circ} \mathrm{C}$ & $\tau_{\mathrm{o}}\left(\mathrm{N} / \mathrm{m}^{2}\right)$ & $\mathrm{K}_{\mathrm{b}}(\mathrm{Cp})$ & $\tau_{\mathrm{o}}$ & $\mathrm{K}_{\mathrm{b}}$ \\
\hline $20^{\circ} \mathrm{C}$ & 2.3 & 41.8 & 0.8 & 21.2 \\
\hline $40^{\circ} \mathrm{C}$ & 1 & 36.2 & - & 9.9 \\
\hline
\end{tabular}

The experimental kinematic viscosities for $\mathrm{LiClO}_{4}-3 \mathrm{NH}_{3}$ and $\mathrm{LiSO}_{3} \mathrm{CF}_{3}-2.9 \mathrm{NH}_{3}$ solvates, were converted to absolute viscosities. Arrhenius plots for the absolute viscosities $\eta$, are shown in Fig. 2 ; it can be seen that $\ln \eta=f(1 / T)$ is a straight line in the whole range of temperature (with a 
better linearity coefficient for perchlorate curve than for the triflate one). The variations of $\ln \eta$ vs $(1 / \mathrm{T})$ can be described by an Arrhenius type relation

$$
\eta=A_{0} \exp W \eta /(R T)
$$

the slope " $\mathrm{d} \ln \eta / \mathrm{d}(1 / \mathrm{T})$ " corresponding to the energy $W \eta$ of the viscous flow (see table III).

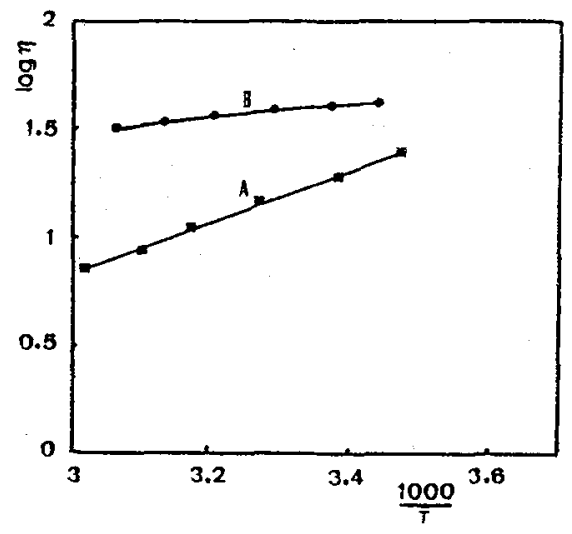

Fig 2 : Absolute viscosity data as function of temperature for $\mathrm{LiClO}_{4}-3 \mathrm{NH}_{3}(\mathrm{~A})$ and $\mathrm{LiSO}_{3} \mathrm{CF}_{3}-2.9 \mathrm{NH}_{3}(\mathrm{~B})$.

\begin{tabular}{|c|c|}
\hline & $W \eta$ Kcal.mol-1 \\
\hline $\mathrm{LiSO}_{3} \mathrm{CF}_{3} \cdot 2.9 \mathrm{NH}_{3}$ & 1.1 \\
\hline $\mathrm{LiClO}_{4} \cdot 3 \mathrm{NH}_{3}$ & 6.1 \\
\hline \multicolumn{2}{|c|}{ Table III }
\end{tabular}

For $\mathrm{LiSO}_{3} \mathrm{CF}_{3}-2.9 \mathrm{NH}_{3}, \tau_{0}$ is significantly higher and $\mathrm{W}_{\eta}$ significantly lower than the values obtained for $\mathrm{LiClO}_{4}-3 \mathrm{NH}_{3}$. We can conclude from high $\tau_{\mathrm{o}}$ value that secondary interactions $(\mathrm{H}$ bond for instance) create bonds, partially broken at $45^{\circ} \mathrm{C}$, between the aggregates in triflate ammoniates; the activation energy of viscous flow $W \eta$ could be correlated to the ionic interactions which are more important in $\mathrm{LiClO}_{4}$ ammoniate (low value of $W_{\eta}$ ) than in $\mathrm{LiSO}_{3} \mathrm{CF}_{3}$ ammoniate.

\subsection{Lithium metal stability with respect to ammoniates.}

$\mathrm{LiNO}_{3}$ and $\mathrm{Li}$ triflate ammoniate reactivity toward $\mathrm{Li}$ metal was investigated at $20^{\circ} \mathrm{C}$. A thick, grey deposit was formed on $\mathrm{Li}$ in both solvates. The film thickness was observed to grow as a function of time. The results of lithium corrosion study showed that the lithium corrosion rate in $\mathrm{LiNO}_{3}$ $2 \mathrm{NH}_{3}$ was higher than in $\mathrm{LiSO}_{3} \mathrm{CF}_{3}-2 \mathrm{NH}_{3}$. To explain the differences in the reactivity of nitrate and triflate solvates (possessing the same $\mathrm{x}$ ) toward $\mathrm{Li}$, we have determined their phase diagrams.

$\mathrm{LiNO}_{3} \times \mathrm{NH}_{3}$ at $+20^{\circ} \mathrm{C}$ : Liquid range was obtained for $1.6<x<3.1$; for $\mathrm{x}>3.1$, saturation occurs and no further ammonia is absorbed under 1 bar.

$\mathrm{LiSO}_{3} \mathrm{CF}_{3}-\mathrm{y} \mathrm{NH}_{3}$ at $+20^{\circ} \mathrm{C}$ : For $1.5<\mathrm{y}<3$, the ammoniate is a liquid. For $\mathrm{y}>3$ a gel-like consistency is observed, under 1 bar. 
The phase diagrams of $\mathrm{LiNO}_{3}-\mathrm{x} \mathrm{NH}_{3}$ and $\mathrm{LiSO}_{3} \mathrm{CF}_{3}-\mathrm{y} \mathrm{NH}$ are shown Fig.3. The higher corrosion rate of $\mathrm{Li}_{\text {in }} \mathrm{LiNO}_{3} \times \mathrm{NH}_{3}$ (particularly for $\mathrm{x}>2$ ) is due to the structure in which a part of $\mathrm{NH}_{3}$ molecules are labile (cf the decrease of freezing point $\mathrm{PF}$ vs $\mathrm{NH}_{3}$ concentration) and can react onto lithizm. In the quasi-gel structure of the triflate ammoniate ( $\mathrm{cf}$ the independence of $\mathrm{PF}$ vs $\mathrm{NH}_{3}$ concentration), the "inter-aggregate" $\mathrm{NH}_{3}$ molecules are not labile and cannot react dramatically onto lithium metal, thus the reaction stops. These results ate in agreement with conductivity measurements.

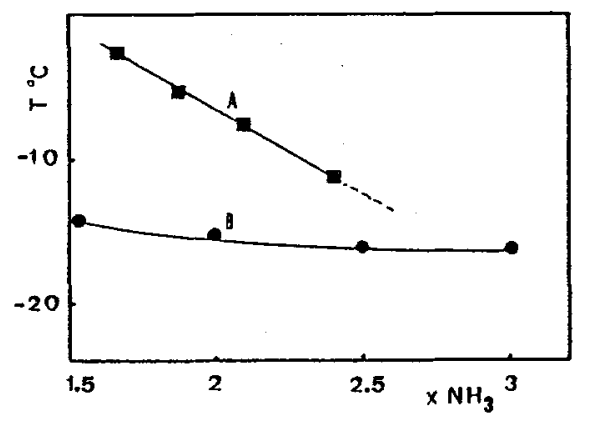

Fig 3 : Freezing point of $\mathrm{LiNO}_{3}-x \mathrm{NH}_{3}$ (A) and $\mathrm{LiSO}_{3} \mathrm{CF}_{3}-\mathrm{x} \mathrm{NH}_{3}$ (B) systems.

\subsection{Thermodynamic stability of the ammoniates}

For manufacturing Li batteries with ammoniates as non aqueous electrolytes, it is essential to know the thermodynamic stability of these solvates as a function of the temperature. We have approached this quantification, in $\mathrm{NH}_{3}$-salt bonding energy, by $\mathrm{p}\left(\mathrm{NH}_{3}\right)=\mathrm{f}(\mathrm{T})$ measurements $\left(\mathrm{p}\left(\mathrm{NH}_{3}\right)\right.$ is the vapor pressure of ammonia in equilibrium with ammoniates) for different compositions as shown in Fig.4.

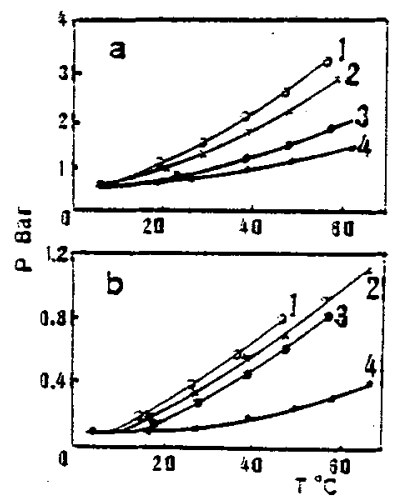

Fig 4 : Vapor pressure at various temperatures of a) LiNO3-x NH3 $[x=2.59(1), 2.25$ (2), $2.05(3), 1.66$ (4)] b) LiSO3CF3-x NH3 [ $x=2.45$ (1), 2.2 (2), 1.95 (3), $1.7(4)]$.

The values of $\mathrm{pNH}_{3}$ of triflate systems are smaller than for nitrate systems indicating the better thermodynamical stability of $\mathrm{LiSO}_{3} \mathrm{CF}_{3}-\mathrm{y} \mathrm{NH}_{3}$ amoniate in the whole temperature range, in agreement with our other measurements on the structure of $\mathrm{LiNO}_{3}$ and $\mathrm{LiSO}_{3} \mathrm{CF}_{3}$ liquid ammoniates. 


\section{Conclusion}

Some selected properties of lithium salt ammoniates have been determined. These investigations have shed light on our understanding of the solvation mechanisms of $\mathrm{Li}^{+}$cation and $\mathrm{NO}_{3}^{-}, \mathrm{ClO}_{4}^{-}, \mathrm{SO}_{3} \mathrm{CF}_{3}^{-}$anions showing the existence of structures depending on the nature of anions. On the one hand for $\mathrm{NO}_{3}^{-}$and $\mathrm{ClO}_{4}^{-}$the ion-pair interactions prevent large aggregates structure, like in fused salts, on the other hand for $\mathrm{SO}_{3} \mathrm{CF}_{3}{ }^{-i t}$ is the revese. For these reasons, nitrate and perchlorate ammoniates possess a good conductivity and react on lithium metal because ammonia is relatively free; triflate anion which possesses an extreme Lewis basicity character, confers good thermodynamical stability to $\mathrm{Li}$ triflate ammoniate with vitreous structure at low temperature indicating the predominance of aggregates which trap $\mathrm{NH}_{3}$ molecules.

$\mathrm{SO}_{3} \mathrm{CF}_{3}{ }^{-}$anion seems the best $\mathrm{Li}^{+}$counterion for battery electrolytes based on ammoniates ; it prevents electrolyte freezing at moderately low temperature and it lowers the reactivity toward lithium, in mixture with an anion which gives a high conductivity.

Acknowledgements : The authors are indebted to DRET for its financial support.

\section{References}

/1/ J. BADOZ-LAMBLING M. BARDIN, M. HERLEM, G. ROBERT and A. THIEBAULT Fr. Patent 2529018 (1982) and U.S. Patent 4446215n (1984).

/2/ B. FAHYS and M. HERLEM, J. Power Sources, 34 (1991) 183-188.

13/ J.J. LAGOWSKI, "The chemistry of non-aqueous solvents", Vol. 2, Academic Press, New-York, (1967).

/4/ M.H. COHEN and D. TURNBULL, J. Chem. Phys., 31 (1959) 1164.

/5/ R.G. PEARSON, J. Am. Chem. Soc., 85 (1963) 3533.

/6/ V. GUTMANN, Electrochimica Acta, 21 (1976) 661-670. 